\title{
Ceratopea billingsi (Gastropoda) from the Early Ordovician of Kronprins Christian Land, eastern North Greenland
}

\author{
John S. Peel \\ Grønlands Geologiske Undersøgelse, Øster Voldgade 10, DK-1350 København K, Danmark.
}

The name Ceratopea is generally associated with a horn or claw-shaped operculum locally common in late Early Ordovician carbonates, the parent gastropod shell being much less well known (Yochelson \& Bridge, 1958; Yochelson, 1979). Ceratopea is recorded from both North and East Greenland. Yochelson \& Peel (1975) described C. ankylosa and C. unguis from the Wandel Valley Formation of Peary Land, eastern North Greenland, and the latter species also occurs in the Nunatami Formation of Washington Land, some $600 \mathrm{~km}$ to the west (Peel \& Yochelson, 1979). In 1964, Yochelson described two species of Ceratopea from the Narwhale Sound Formation of East Greenland, one in open nomenclature and the second, a new species to which he gave the name $C$. billingsi.

In 1980, specimens of $C$. billingsi were collected from strata assigned to the Wandel Valley Formation in Kronprins Christian Land, some $200 \mathrm{~km}$ east-south-east of outcrops of the same formation in Peary Land, which yield Ceratopea. A good correlation is thus established between the lower part of the Wandel Valley Formation of Kronprins Christian Land and lower beds of the Narwhale Sound Formation in East Greenland. In addition, $C$. billingsi is also recorded frome Durness limestone of north-west Scotland and from the Cape Norman area of Newfoundland (see references and discussion in Yochelson, 1964).

An as yet unanswered question concerns the apparent absence of $C$. billingsi in Peary Land, and $C$. unguis and $C$. ankylosa in Kronprins Christian Land, respectively. Precise age relationships of these three late Early Ordovician species are uncertain and some difference may be present. However, it is equally possible that slight differences in environment may be responsible for the mutually exclusive relationship. Lower beds of the Wandel Valley Formation in Kronprins Christian Land are more limey and appear slightly more marine than the more dolomitic type sequence of the formation in Peary Land.

\section{References}

Peel, J. S. \& Yochelson, E. L. 1979: Ceratopea (Gastropoda from Washingtow Eathd, western North Greenland. Rapp. Grønlands geol. Unders. 91, 87,91

Yochelson, E. L. 1964: The Early Ordóvician gastropod Ceratopea from East Greenland. Meddr Grønland 164(7), 12 pp. a...iv

Yochelson, E. L. 1979: Gastropod opercula as objects for paleobiogeographic study. In Gray, J. \& Boucot, A. L. (edit.) Historical biogeography, plate tectonics, \& the changing environment, 37-43, Oregon State U.P.

Yochelson, E. L. \& Bridge, J. 1958: The Lower Ordovician gastropod Ceratopea. Prof. Pap. U.S. geol. Surv. 294-H, 281-302.

Yochelson, E. L. \& Peel, J. S. 1975: Ceratopea and the correlation of the Wandel Valley Formation, eastern North Greenland. Rapp. Grønlands geol. Unders. 75, 28-31. 